\title{
LA LEYENDA DE LA LAGUNA DEL VOLCAN BARVA
}

\author{
Kattia Chinchilla Sánchez
}

\begin{abstract}
This article is a symbolic analisis of two mythical elements very frecuent: the tree and the snake, in the leyend of the Barva Volcano's lagoon.
\end{abstract}

La palabra leyenda encierra, en su significado, un elemento de verdad; se contrapone con el vocablo mito que, para los profanos, es mentira. Debemos establecer aquí ciertas pautas metodológicas: el mito, en primer lugar, es una historia sagrada, pero sobretodo es un relato que manifiesta la sacralidad. Por tanto, el mito, lejos de ser una ficción, es una verdad apodíctica, ya que evidencia hechos sagrados, los cuales se caracterizan por ser verídicos ante los ojos de los creyentes. Veamos una definición común:

"(del latín, 'lo que se lee'). Relato tradicional en el que existe un elemento de verdad (el mito, por el contrario, es pura ficción)"1.

Contrariamente al saber popular, el mito es una historia verdadera, ejemplar, revelada, repetible, sagrada y, por ende, significativa. Ahora bien, ¿por qué hemos relacionado mito con leyenda? El mito, una vez degradado, se convierte en leyenda, pero mantiene intacta su estructura mítico-simbólica:

"El mito puede degradarse en leyenda épica, balada o novela o
sobrevivir en formas menores - supersticiones, costumbres,
nostalgias, etc.- sin perder por ello su estructura ni su alcance"2.

Es por ello que hemos elegido la leyenda de la laguna del Volcán Barva, la cual está llena de matices míticos y simbólicos. La leyenda comienza diciendo que "hace muchos años", antes de la llegada de los españoles, el país estuvo dominado por los aztecas. El origen o el comienzo de algo tiene un gran prestigio mítico: in illo tempore las cosas se empezaron a formar, todo comenzaba a ser. Todo relato se ubica en un pasado absoluto, de ahí que Ortega y Gasset hable de que el mito es un relato con hálito de pretérito; es la famosa frase de los cuentos "había una vez". Al pueblo, en el valle de Abra, cerca de lo que es hoy San Josecito de San Rafael de Heredia, llegó una comitiva de indios extranjeros. Este es un elemento importante: lo sagrado es lo 'otro' por excelencia. Por tanto, los extraños representan el concepto, seres de 'otro' lugar que traen consigo objetos mágicos. Como por ejemplo en la novela de García Márquez, Cien Años de Soledad, los gitanos traían los grandes adelantos al pueblo de Macondo. Asimismo, durante la conquista, los indígenas veían divinidades en los españoles; muchos aseguran que los ángeles y el propio Dios es extraterrestre, por lo que el fenómeno de los seres del espacio reviste caracteres sagrados para quienes creen en ellos, son ajenos a la naturaleza humana y representan el sumo bien.

La comitiva de indios extranjeros llevaba consigo un arbolito de matasano con una serpiente enrollada en él. El árbol de matasano (Casimiroa sapota) crece en lugares cálidos y templados; produce una fruta esférica de color verde amarillento, muy dulce y jugosa, que es muy apetecida por las serpientes. Ademas se considera indigesta. Curiosamente, sus hojas se utilizan en el tratamiento de la diabetes. Volviendo a nuestra leyenda, al poner la serpiente en el suelo, comenzó a brotar agua. El árbol es uno de los temas simbólicos más extendidos. El árbol implica la vida en perpetua evolución, representa el 
carácter cíclico, cósmico, muerte y regeneración. Une los tres niveles cósmicos: cielo, tierra e infierno, o sea, es un axis mundis; reúne el mundo ctónico y el mundo uránico:

"El árbol está cargado de fuerzas sagradas porque es vertical, porque crece, pierde hojas, pero las recobra, es decir, se regenera (muere y resucita) infinidad de veces" ${ }^{3}$.

Como el árbol del paraíso, éste tiene una serpiente. El árbol de la ciencia del bien y del mal supone un símbolo de sabiduría. Tal vez los indígenas extranjeros estaban introduciendo la sabiduría en el poblado, pues la presencia de la serpiente así lo conforma: es símbolo de la sabiduría telúrica, ya que conoce los secretos de la tierra4.

El árbol reúne todos los elementos: el agua circula con su savia, la tierra se integra a su cuerpo con sus raíces, el aire alimenta sus hojas y el fuego surge de su frotación. Por tanto, es una imagen del microcosmos.

El árbol, de carácter axial como ya dijimos, es también imagen del mundo (imago mundi) y muchas culturas así lo consideran: el roble en Galia, el tilo entre los germanos, el fresno en Escandinavia, el olivo en el Islam. Asimismo, el árbol de la vida es el Arbol central, como el árbol edénico, las manzanas de oro del jardín de las Hespérides, los melocotones del Haoma en Irán. El árbol es símbolo de la regeneración perpetua y, por tanto, de la vida. Es también una imagen fálica, siendo éste generador de la vida por excelencia: el falo erecto es el tallo que no se rompe.

"El simbolismo sexual del árbol es doble. Exteriormente, el tronco erecto es una imagen fálica (...) La leyenda de los pueblos cuenta con innumerables padres - árboles. Por otra parte, el hueco de los árboles interviene a menudo como una matriz, análogo a la gruta"5.

En su calidad de agente totalizador (axis mundis), existe una relación simbólica entre el árbol y el hombre, a partir del rasgo vertical de ambos. El árbol como símbolo del hombre queda asentado en el antiguo rito del casamiento de los árboles.Además, en la iconografía, concretamente en el manuscrito número 1316 del Museo Británico en Londres, el árbol sale del falo del hombre ${ }^{6}$. Ritualmente, los futuros esposos siembran una pareja de árboles, uno macho y el otro hembra? . De tal forma, esta unión vegetal asegurará la fertilidad de su pareja humana y homóloga. Estos ritos son muy frecuentes en la India.
"El matrimonio de árboles se efectúa generalmente cuando las mujeres, después de varios años de matrimonio, no han tenido todavía hijos. En este caso, en el día y en la hora fasta, marido y mujer se dirigen a la orilla del estanque y plantan cada uno un árbol; la mujer una tierna higuera de las pagodas, y el marido, un mango (...) Pasado algún tiempo, esos árboles se convierten en objeto de culto"s.

El árbol de la vida es también el árbol de la muerte e inversamente. Como se verá más adelante, la llegada del árbol y la serpiente traerá consigo la muerte en el poblado.

"En el estrato más primitivo, más que un árbol cósmico y otro del conocimiento, o del bien y del mal, hay un árbol de la vida y otro árbol de la muerte"?

El árbol está custodiado por un monstruo, en este caso una serpiente, como en el Paraíso y como en el jardín de las Hespérides, siendo el árbol el que concede la inmortalidad, como cuando Gilgamesh lo busca en el fondo del océano.

"Al árbol se asocia frecuentemente la fuente y también el dragón - la serpiente. El símbolo LVII de la Ars Symbolica del Boschius, muestra un dragón junto al árbol de las Hespérides"10.

Las raíces del árbol se homologan con serpientes y dragones. La serpiente enrollada al árbol implica un símbolo helicoidal o espiral, de categoría selénica; de allí la consecuencia, el brotar agua, de dominio lunar. El árbol como eje del mundo es rodeado por el conjunto de ciclos, que representa la serpiente.

Hablemos ahora de la serpiente. Ella, visible sobre la tierra, en el instante de su manifestación es una hierofanía. Rápida como el relámpago, gusta vivir en las oquedades de la tierra, de allí su carácter ctónico-funerario. Es enigmática y sexualmente reúne los contrarios: es hembra y también macho, gemela en sí misma. La serpiente está ligada con la vida y con la eternidad, pues muda de piel y se mantiene siempre joven ${ }^{11}$. Al ser anillada, la serpiente es la base del eje del mundo, además es punto de unión entre el cielo, la tierra y el infierno: habita en las grietas de la tierra (infiemo), se arrastra sobre el suelo (tierra) y se eleva al atacar (cielo).

Serpiente y círculo se unen cuando nos referimos al ouróboros: la serpiente que se muerde la cola. Es la unión sexual en sí mismo, el autofecundador permanente; es la vida y la muerte a la vez, presencia de los opuestos:

"La dialéctica material de la vida y de la muerte, la muerte que sale de la vida y la vida que sale de la muerte"12. 
Espiritu de las aguas, subterráneas y superficiales, muchos ríos tienen el nombre de Ophis o de Draco ${ }^{13}$. En nuestro caso, es marcada la relación de la serpiente y el agua; su sola presencia hace que de la tierra mane el agua. Además los extranjeros que la portan son aztecas,para quienes es trascendente el concepto de la serpiente emplumada: el mito del pájaro-serpiente coincide con las regiones más antiguas de la cultura del maiz. La serpiente emplumada es una nube de lluvia. En algunas culturas se invoca a la serpiente en los momentos de sequía o de lluvia abundante. Estas son valoraciones fecundantes y masculinas.

Sin embargo, la serpiente engulle, característica nétamente femenina. Además esta serpiente, luego de la formación de la laguna del Volcán Barva, sale de ella para devorar a los niños: aparece aquí como la gran regeneradora e iniciadora, dueffa del vientre del mundo. Además todas las diosas de la naturaleza tienen a la serpiente por atributo: Cibeles, Deméter, diosas también de rasgo selénico, siendo la luna la gran regente de las aguas:

"Tanto por estar sujetas a los ritmos (lluvia y mareas) como por ser germinativas, las aguas están regidas por la luna. La luna está en las aguas y de la luna viene la lluvia"14.

Dueña de las mujeres y de la fecundidad, la serpiente se considera la culpable de las menstruaciones; entre los persas, por ejemplo, la primera mujer tuvo su primera regla al dejarse seducir por una serpiente, y en medios rabínicos, es por Eva,quien sostuvo relaciones con la serpiente edénica. Esto sin duda se debe al carácter fálico de la serpiente ${ }^{15}$.

Las serpientes son protectoras de las fuentes de vida y de la inmortalidad. Nuestra serpiente es repudiada por los nativos, así que los extranjeros la colocaron en la cumbre del monte, donde del suelo brotó agua sin cesar hasta crear la laguna del Volcán Barva. Este monte es una montaña cósmica, por donde pasa el axis mundi, lugar donde se junta el Cielo con la Tierra, símbolo de ascensión e iniciación. La serpiente resguarda celosamente la laguna. Simbólicamente, el ondular de la serpiente se homologa con las ondas del agua.

"Los dragones, las serpientes, las conchas, los delfines, los peces, etc., son emblemas del agua; se esconden en las profundidades del océano, el abismo infunde en ellos su fuerza sagrada; cuando duermen en los lagos o cruzan los ríos dis- pensan la lluvia, la humedad y las inundaciones, controlando así la fecundidad del mundo"16.

Así hemos visto cómo dos símbolos están presentes en esta leyenda: árbol y serpiente. El árbol de matasano cumple un rol de centro y la serpiente es un espíritu de las aguas.Por otra parte, hemos demostrado que el árbol es andrógino al igual que la serpiente.Unidos simbolizan la inmortalidad y la regeneración periódica. Los indígenas le ofrecían el sacrificio de los niños a la temida serpiente de la laguna. Los padres de los niños inmolados pasaban a una especie de hacienda que había en el fondo de la laguna, donde se aprovisionaban de comestibles.

\section{Citas bibliográficas y notas explicativas}

1. Royston Pike, Edgar, Diccionario de religiones, México: F.C.E., 1991, pág. 281

2. Eliade, Mircea, Tratado de historia de las religiones, Madrid: Cristiandad, 1981, pág. 431.

3. Eliade, Mircea, op.cit., pág. 277.

4. Recuérdese el valor de la serpiente Pitón en el misterio de los oráculos. La serpiente por vivir en las oquedades y por arrastrarse sobre la tierra está íntimamente ligada a ella. Además, la sabiduría ancestral es potestad de la diosa telúrica: Gea, Metis, Temis. Inclusive, las mujeres de la antigüedad se desempeñaban como sacerdotisas. Por ser una facultad femenina, en el don de la mántica la presencia de la bruja, conocedora de secretos, es indiscutible, así como la sabiduría de la madre.

5. Chevalier, Jean y Alain Gheerbrant, Diccionario de símbolos, Barcelona: Herder, 1988, pág. 120. Así pues hay árboles masculinos y femeninos. Por ejemplo, entre los chuvashos (antigua Unión Soviética) el tilo se usa en ritos fúnebres para mujeres, mientras que el roble se usa para los varones.

6. En esta relación hombre-planta, Eliade nos puntualiza la solidaridad existente entre el crecimiento del árbol y el crecimiento del hombre. "En Mecklembrugo, se entierra la placenta del recién nacido al pie de un árbol frutal; en Indonesia, se planta un árbol en el lugar en que ha sido enterrada." (Eliade, Mircea, op. cit., pág. 311). Curiosamente aquí en Costa Rica, en Jardines del Recuerdo se sembraba un árbol cuando se enterraba a alguna persona, como si la vida del ser humano continuara místicamente en la del árbol.

7. Eliade, Mircea, op. cit., pág. 314

8. Chevalier, Jean y Alain Gheebrant, op. cit., pág. 127 
9. Cirlot, Juan Eduardo, Diccionario de símbolos, Barcelona: Labor, 1985, pág. 79

10. loc. cit.

11. Por ejemplo, los caldeos tenían una sola palabra para vida y serpiente.

12. Chevalier, Juan y Alian Gheebrant, op. cit., pág. 927

13. Aqueloo, el río más grande de Grecia, toma la forma de serpiente y de toro al enfrentar a Heracles. Ambos símbolos representan el poder fecundante del semen y del agua: son imágenes del dios fecundador.

14. Eliade, Mircea, op. cit., pág. 174

15. En Francia, en Alemania y en Portugal, las mujeres creen que una serpiente se puede introducir en sus bocas y así dejarlas encinta, sobre todo en el período menstrual.

16. Eliade, Mircea, op. cit., pág. 217

\section{Bibliografía}

Cirlot, Juan Eduardo, Dicionario de símbolos, Barcelona: Labor, 1985
Chevalier, Jean y Alain Gheebrant, Diccionario de símbolos, Barcelona:Herder, 1988

Eliade, Mircea, La búsqueda, Buenos Aires: La Aurora, 1984

Lo sagrado y lo profano, Barcelona: Labor/Punto Omega, 1985

Mito y realidad, Barcelona: Labor/Punto Omega,1983

Tratado de historia de las religiones, Madrid: Cristiandad, 1981

Grimal, Pierre, Diccionario de mitología griega y romana, Barcelona: Paidós, 1984

Masson, Hervé, Diccionario-manual de esoterismo, México: Roca, 1975

Zeledón, Cartín, Elías (compilador) Leyendas costarricenses, San José: Museo de Cultura Popular, 1989 